\title{
Dynamics of Inter-actor Relations in Community Social Networks in the Management of the Citarum Riverbanks
}

\author{
Rudi Saprudin Darwis ${ }^{1}$, Risna Resnawaty ${ }^{2}$, Eva Nuriyah Hidayat ${ }^{3}$, Naya Defisa ${ }^{4}$ \\ \{rudi.darwis@unpad.ac.id ${ }^{1}$, risna.resnawaty@unpad.ac.id ${ }^{2}$, eva.nuriyah@unpad.ac.id ${ }^{3}$ \} \\ Universitas Padjadjaran, Indonesia ${ }^{1,2,3,4}$
}

\begin{abstract}
Citarum river bank management which is comprehensive and integrated involves various parties in a social network. This research will describe the dynamics of the relationships between actors in the collaborative process in the social networks that are built. The research method used in this study is a descriptive study research method with a qualitative approach. The aspects studied include the actors involved, the distribution of resources, opportunities to exchange, exchange relations, and network structure. The results showed that the actors involved in managing the Citarum riverbank consisted of individuals and groups with diverse professional backgrounds but could complement each other. The valuable sources distributed by actors include money, time, thought, and energy through socialization, community service, and coordination meetings. To engage in exchange relations, the factors that give rise to opportunities for exchange are due to personal awareness and the presence of work instructions. In the aspect of exchange relations, the reciprocal elements obtained by the actors include changes in behavior, appreciation, and also personal satisfaction. Network structures are formed as a result of similar goals and attachments among actors. This attachment is in the form of a cooperative relationship that is mutually beneficial and complements one another.
\end{abstract}

Keywords: Relationships Inter-actors, Social Networks, Riverbanks, Citarum.

\section{Introduction}

The Citarum River has a very strategic function for the lives of people in the areas it passes through. Citarum River supplies the water needs of approximately 28 million people in 12 cities/ regencies located in Jakarta, Bekasi, Karawang, Purwakarta and Bandung. In addition, this river is also a source of power that drives the turbines of power plants (PLTA) in 3 (three) reservoirs that are in the flow. This hydropower plant supplies electricity for the Java and Bali regions. However, the irony is, the facts of the usefulness of the Citarum River are not matched by the maintenance of the river [1].

In 2018 the Citarum River was named the river with the highest level of pollution in the world by the World Bank. Even the Regional Environmental Impact Management Agency (Bapedalda) of West Java states that the status of water quality in the Citarum River has reached a heavily polluted stage. Pollution at this level if left unchecked for a long period of time will have a very bad impact on the health of the people who supply their daily water needs from the Citarum River. 
Citarum River pollution is seen from the presence of trash and other B3 waste along with the river flow. According to the Regional Environmental Management Agency (BPLHD) of Bandung Regency, $70 \%$ of the waste along the Citarum River flows from domestic waste and the remaining $30 \%$ comes from factory waste from approximately 500 factories in the watershed. This data shows that the biggest source of waste producers that pollute the Citarum River actually comes from the community, both from household waste and waste generated from sanitation. Community behavior is the key to the cause as well as the solution to the problem of solving the Citarum River pollution problem.

Green states that community behavior in environmental health includes behavior in relation to clean water, sewage, sewage (liquid and solid), healthy homes, cleaning pet cages. Community behavior in maintaining environmental health is influenced by several factors, namely: (1) predisposing factors (related to knowledge, beliefs and values), (2) enabling factors (related to facilities), and (3) reinforcing factors (related to influence community leaders, religious leaders, and health workers) [2].

The condition of environmental health in which the community lives depends on how the community treats it. In order to provide good carrying capacity for the community, environmental management must be controlled to suit the needs of the social system and the sustainability of the ecosystem so that life continues. Cooperation in maintaining the Citarum River must not only grow from a part of the community, but it requires good coordination between one community group and another community group. In this case, a social network is needed to build a community that lives along the Citarum River.

According to Arsyad (2015), a social network is born from social relations that become cooperation because individuals or groups have different access to valuable resources, such as access to natural resources, information or power [3]. The formation of social networks is beneficial for individuals or groups in meeting their needs and achieving their goals. Van Dijk describes social networks as social systems with concrete ties in abstract relationships; social networks consist of actors who interact with each other (nodes) and the fabric of relationships between actors (links) [4].

Taking into account the nature of the problems in the Citarum Watershed, the management of the Citarum Watershed requires a social network to maximize the management. The existence of this social network can be used to see how the exchange relations (social relations) that occur between the actors (actors) in it. In addition, this social network can also show how each other plays a role in the management of the Citarum River Basin. A good and deep understanding of this social network will enable the optimal management of the Citarum watershed.

\section{Research Methods}

The method used in this research is descriptive method with a qualitative approach. The descriptive research method explains the description of community social networks in the environmental management of the Citarum River Basin. This research was carried out in one of the areas in the Citarum River Sector Sector 7, Baleendah District, Bandung Regency which was identified as having a fairly severe level of waste problems, with a large amount of waste accumulation in the Citarum watershed in the area. Sector 7 is a designation for one of the regions in the Citarum watershed subdivision in the Citarum Harum Program. By using this approach, the research objective is to make a systematic and accurate description or 
description of the facts, characteristics, and relationships in various aspects of the social network issues in the management of the Citarum Riverbanks environment. To obtain accurate data regarding social networks in the management of the Citarum Riverbanks, the informants of this study are those who know about the social network in the Citarum Riverbanks management in Sector 7, Baleendah District, Bandung Regency. The informants referred to were the local government, community leaders, Sector 7 Commander, manager of the Citarum Harum program, and local organizations concerned with the management of the Citarum River Basin. Data were collected using in-depth interview techniques that were supplemented by observations of the condition of the community and the environment in the Citarum River Basin. The aspects of research that are the focus of this study use the exchange network components proposed by Emerson [5], namely: individual and collective actors, valuable sources distributed among actors, opportunities for exchanges, exchange relations, and network structures.

By using the components of the exchange network can be described how the relationship between actors in living a collective life as a social network. The dynamics of relationships in social networks can be described from the position of the community individually or in groups, the existence and types of valuable sources in the network, the mechanism of distribution of valuable resources in the network, the form of stimulation or opportunity for exchange, the existence of reciprocal elements, sacrifice, and advantages in exchange relations, as well as the results of analysis of the network structure formed between the actors. These things can occur because social networking is an effort to work together to meet the needs of other parties. In collaboration with social life there will be a social exchange that has elements of reward, sacrifice, and profit that influence each other.

\section{Results and Discussion}

Every person will be in a relationship with certain people or parties who are relevant to their needs, both individually and collectively. For this reason, according to Agusyanto [6] social networks are formed in society because basically humans cannot relate to all human beings; relationships are always limited to certain people. Each person learns from his experience to choose and develop social relationships that are limited in number compared to the number of series of social relationships available, adapted to the needs that exist in individuals so that in an effort to improve living standards also do not use all social relationships that are it has. Within the Citarum River Basin watershed management framework, the parties involved are also limited.

Individuals and groups in community social networks in the management of the Citarum River Basin in Sector 7, Baleendah Subdistrict, Bandung Regency are those who have the knowledge and contribution to the management of the area. The results of the study on individual and group aspects, identified various actors who have professional backgrounds and roles that complement each other in maximizing the management of the Citarum Riverbanks in Sector 7. Each actor identified has a different role and complement each other.

Actors are the main element of concern in analyzing a network. To understand the condition of social networks such as those contained in networks in the management of the Citarum Riverbanks, there are eight main concepts that can be used as a reference for analyzing [7], namely:

a) Actor, can be an individual, corporation, or social unit collectively; 
b) Relationship ties. Actors are associated with social ties in various contexts such as the context of friendship, preferences, etc;

c) Dyad, which is a bond between two actors;

d) Triad, is the relationship between a larger set of actors. Triad analysis is performed to show the balance or transitivity of a relationship;

e) Subgroups. Subgroups of actors are any set of actors that have ties to each other, which can be in the form of dyad or triad;

f) Group, is a collection of actors whose ties can be measured both theoretically, empirically and conceptually.

g) Relations are ties of a particular type between members of a group are relations;

h) Social networks, consisting of a set of boundaries or a group of actors and relations, and relationships defined by the relevant actors.

By using these concepts, the existence of social networks in the management of the Citarum Riverbanks. Also, an overview of the various elements that build social networks can be explained in detail.

The actors involved consisted of elements of the community, TNI, government, NGOs, and also social volunteers. These parties are actors who are bound in social networks and have the same goal, namely managing the Citarum watershed in Sector 7, Baleendah District, Bandung Regency. The community has a large role in the management of the Citarum River watershed, remembering the community is an actor who has been in the Citarum watershed for a long time. In addition, the facts show that the Citarum watershed pollution is mostly caused by household waste. Therefore, it is important for the community to have adequate knowledge so that the management of the Citarum watershed and apply it to daily life.

The presence of the TNI in the Citarum program Must make the TNI have a special position in the management of the Citarum Riverbanks, which is to act as a "controller" in the midst of the community, moreover the TNI will be with the community for at least the next 5 years. The presence of the TNI has made people reluctant to violate regulations in the management of the Citarum Riverbanks that had been mutually agreed upon. TNI personnel will give sanctions to those who have been proven to dump garbage into the Citarum River. The sanction is in the form of direct push-up punishment at the scene; however, stricter sanctions are needed for those who pollute the Citarum watershed because push up penalties are considered too light and do not deter them.

For NGOs, they act as community facilitators in the management process of the Citarum River Basin. They provide assistance in the form of education to the community on the importance of protecting the environment through a humanist approach in the form of social activities carried out and advocacy for the community.

Volunteers have a role as aid workers for the management of the Citarum Watershed in Sector 7 in the form of personnel for physical activities in the field as well as activities that are policy formulating intervention. These volunteers join the activity not routinely every week or month, but if there is an invitation to cooperate with other parties that have been mentioned previously.

The government has a role as the formulator and implementer of policies towards the management of the Citarum Riverbanks. When making government policies usually involve other parties to be able to maximize the management of the Citarum watershed. One of the policies implemented by the government is to invite other parties to participate in environmental management, namely the TNI and NGOs. 
Schematically, the relationship between the actors is as follows:

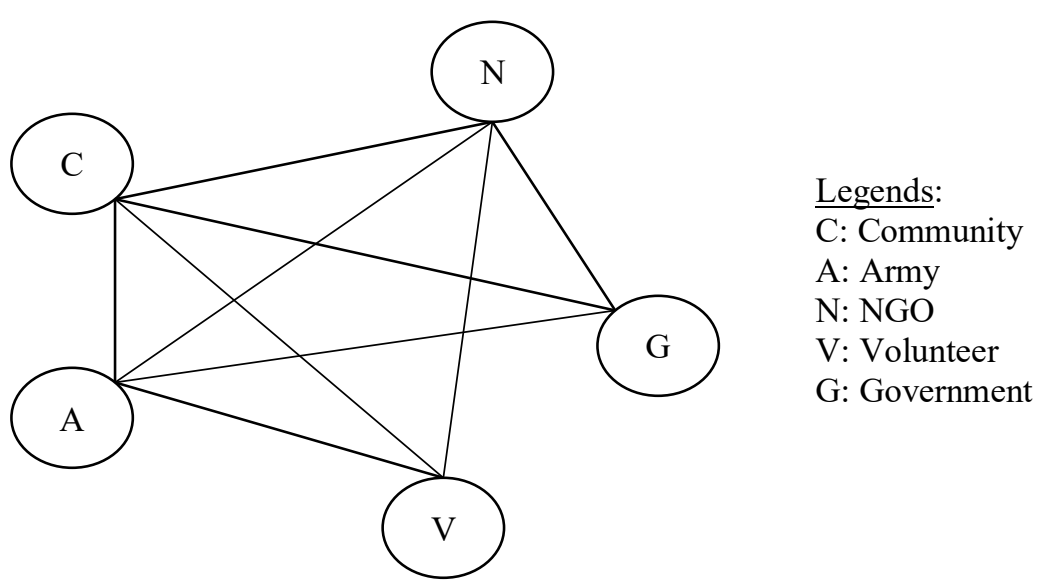

Fig. 1. Exchange Relations Between Actors

Among the actors there was an exchange of relations in the social network management of the Citarum River Basin in Sector 7, Baleendah District, Bandung Regency. Although not all actors have an exchange relationship, these actors form a network. Actors from the community, TNI and NGOs have exchanges with actors from all parties. The conditions are different from the relationship between volunteers and the government which shows no relationship. The volunteers did not establish relations with the government because they did not want to deal with bureaucracy which was considered difficult and limited contributions.

Matrix 1. Distribution of Valuable Resources

\begin{tabular}{|l|c|c|c|c|c|}
\hline \multicolumn{1}{|c|}{ Actor } & Community & Army & NGO & Volunteer & Government \\
\hline Money & $\sqrt{ }$ & $\sqrt{ }$ & $\sqrt{ }$ & $\mathrm{x}$ & $\sqrt{ }$ \\
\hline Time & $\sqrt{ }$ & $\sqrt{ }$ & $\sqrt{ }$ & $\sqrt{ }$ & $\sqrt{ }$ \\
\hline Thought & $\sqrt{ }$ & $\mathrm{x}$ & $\sqrt{ }$ & $\sqrt{ }$ & $\sqrt{ }$ \\
\hline Energy & $\sqrt{ }$ & $\sqrt{ }$ & $\sqrt{ }$ & $\sqrt{ }$ & $\sqrt{ }$ \\
\hline
\end{tabular}

The distribution aspects of valuable resources in social networks in the management of the Citarum River Basin in Sector 7, Baleendah District, Bandung Regency have different ways of distributing and valued resources. The distribution of valuable sources is itself a process of distribution or distribution of valuable resources among the actors. In general, valuable resources distributed by the actors include money, time, thought, and energy. As for the mechanism, the actors in general distribute valuable sources through socialization, community service, and coordination meetings.

Distribution mechanisms also tend to be different for each valuable source. This money is distributed through community service activities or the procurement of waste management tools. The time that the actors have contributed to the management of the Citarum River watershed ranges from 1 year to more than 5 years. Most of the power is distributed by the actors through community service activities. As for the element of thought, it tends to be distributed during coordination meetings (Matrix 2). 
Related to the coordination carried out in the network, Bharosa, et.al (2010) found that relief workers are often more concerned with receiving information from others than with providing information to others who may benefit [8].

Matrix 2. Distribution Mechanisms of Valuable Resources

\begin{tabular}{|l|c|c|c|c|c|}
\hline \multicolumn{1}{|c|}{ Actor } & Community & Army & NGO & Volunteer & Government \\
\hline Socialization & $\sqrt{ }$ & $\sqrt{ }$ & $\sqrt{ }$ & $\sqrt{ }$ & $\sqrt{ }$ \\
\hline Community service & $\sqrt{ }$ & $\sqrt{ }$ & $\sqrt{ }$ & $\sqrt{ }$ & $\sqrt{ }$ \\
\hline Coordination & $\sqrt{ }$ & $\sqrt{ }$ & $\sqrt{ }$ & $\sqrt{ }$ & $\mathrm{x}$ \\
\hline
\end{tabular}

The opportunity to make an exchange refers to the conditions that allow the actors to make an exchange relationship. The actors involved in the management of the Citarum watershed in Sector 7, Baleendah Subdistrict, Bandung Regency conducted an exchange relationship due to different stimulation factors for each actor. Broadly speaking, the factors that encourage actors to make exchanges are due to self-awareness and also the presence of work instructions.

This personal awareness arises due to worrying about the condition of the Citarum River which is increasingly apprehensive because of uncontrolled rubbish and waste as well as disrupting people's daily lives and threatening the lives of the next generation. The emergence of an opportunity to exchange is due to the stimulation of work instructions. These work instructions are generally received by actors who are required to contribute to the management of the Citarum River watershed from various agencies concerned in the management of the Citarum River Basin in Sector 7, Baleendah District, Bandung Regency.

Matrix 3. Opportunities for Exchange

\begin{tabular}{|l|c|c|c|c|c|}
\hline \multicolumn{1}{|c|}{ Actor } & Community & Army & NGO & Volunteer & Government \\
\hline Self-awareness & $\mathrm{x}$ & $\mathrm{x}$ & $\sqrt{ }$ & $\sqrt{ }$ & $\sqrt{ }$ \\
\hline Instructions & $\sqrt{ }$ & $\sqrt{ }$ & $\mathrm{x}$ & $\mathrm{x}$ & $\sqrt{ }$ \\
\hline
\end{tabular}

In accordance with the characteristics of the actors in the network, it appears that the community, the TNI and the government tend to have the opportunity to exchange as a result of instructions from other parties. This is different from what happens to NGOs and volunteers who conduct exchange relations on the basis of personal awareness. They take the opportunity to carry out networking activities based on their awareness and concern to do something with other parties in managing the environment.

The reciprocal relationships obtained by the actors in the management of the Citarum River watershed in Sector 7 include changes in behavior, appreciation, and also the personal satisfaction obtained by the actors in conducting social networking relationships. Changes in behavior, in the form of changes in ability, occur when they realize the urgency of better watershed management; even more so when there arises the desire for a more decent life in his children and grandchildren later. The form of appreciation in the form of praise or material appreciation given to actors who contribute well. This personal satisfaction comes in the form of a sense of satisfaction and pleasure in success in reducing pollution and maximizing the management of the Citarum watershed in Sector 7, Baleendah District, Bandung Regency.

When viewed from the objectives of social relations that form social networks that exist in society, then social networks can be divided into three types [6], namely: First, is a network of power (power), a network of social relations formed by social relations charged with power. In a power network, configurations of interrelations between actors in it are intentional or 
regulated by power. This type of network arises when the achievement of targeted goals requires collective action and configuration of interrelationships between actors which are usually permanent. These power relations are usually aimed at creating the conditions needed to achieve the stated goals. The social units are artificially planned or deliberately structured by power. This type of social network must have a power center that continually reviews the performance of its social units, and reframes its structure for the sake of efficiency. In this case informal controls are inadequate, the problem is that this network is more complex than naturally formed social networks. Thus, this type of social network cannot rely on the awareness of its members to fulfill the obligations of its members voluntarily, without incentives.

Second, the network of interests (interest), is a network of social relations formed by social relations that contain interests. This network of interests is formed by meaningful relationships on specific or specific goals. If the goals are specific and concrete - such as getting a job, goods, or service - then if the goals have been achieved by the culprit, this relationship is usually not sustainable. The structure that emerges from this type of social network is brief and changing. Conversely, if the goals are not as concrete and specific as they are or they are always recurring, then the structure formed is relatively stable and permanent.

Third, the network of feelings (sentiment), is a network formed on the basis of social relations with feelings, and social relations themselves become social goals and actions. The structure formed by these emotional relations tends to be stable and permanent. Social relationships that are formed usually tend to be close and continuous relationships. Among the actors tends to like or dislike other actors in the network. Therefore, emerge a relatively strong emotional control between actors.

In reality on the ground, a social network is not only formed by one type of social network above. However, there is an overlap between the three types of social relations. A social network is considered as a network of interests if the relationships formed within the social network are more dominant for the fulfillment of certain needs or interests. Two other types of social networks, the power network and the feeling network, remain but are not dominant.

\section{Conclusions and Suggestions}

Individual and group actors on community social networks in the management of the Citarum watershed in Sector 7, Baleendah Subdistrict, Bandung Regency consist of parties with different backgrounds and roles that complement each other, namely from the community, TNI, government, NGOs, and also social volunteers. In networking, the actors contribute to the network in the form of valuable resources in the form of money, time, thoughts, and energy through socialization activities, community service, or coordination meetings. Relationships in networking are carried out on the basis of personal awareness or because of obligations and task demands. As a result, from their contributions, the forms of reciprocity obtained by the actors include behavior change, appreciation, and also personal satisfaction. 


\subsection{Acknowledgments}

Thank you to Ms. Naya Defisa which has allowed the author to use the data of his research results for reprocessing by the author for the purposes of making this article.

\section{References}

[1] I. Greenpeace, "IMAZON, Instituto Centro de Vida, Instituto Socioambiental, IPAM, The Nature Conservancy, WWF (2017) A pathway to zero deforestation in the Brazilian Amazon." 2018.

[2] S. Notoadmodjo, Kesehatan Masyarakat Ilmu \& Seni. Jakarta: Rineka Cipta, 2011.

[3] I. Arsyad, Membangun Jaringan Sosial dan Kemitraan. Jakarta, 2015.

[4] V. DIjk, The Network Society. London: SAGE Publications, 2006.

[5] G. Ritzer, "Prosumption: Evolution, revolution, or eternal return of the same?," J. Consum. Cult., vol. 14, no. 1, pp. 3-24, 2014.

[6] R. Agusyanto, Jaringan Sosial dan Kebudayaan: Kasus Arek-Arek Suroboyo. 1991.

[7] S. Wasserman and K. Faust, Social Network Analysis in the Social and Behavioral Sciences. Cambridge: Cambridge University Press, 1994.

[8] N. Bharosa, M. Janssen, and J. Lee, "Challenges and Obstacles in Sharing and Coordinating Information During Multi-Agency Disaster Response: Propositions from Field Exercises, Information Systems Frontiers," vol. 12, pp. 49-65, 2010. 